Jurnal At-Tibyan: Jurnal Ilmu Alqur'an dan Tafsir

Volume 5 No. 2, Desember 2020 (h.325-344)

P ISSN 2442-594X | E ISSN 2579-5708

http://journal.iainlangsa.ac.id/index.php/tibyan

\title{
DE-RADICALIZATION OF INTERPRETATION THE CONCEPT OF JIHAD IN TAFSIR AL-QUSYAIRI
}

\author{
M. Minanur Rohman \\ Institut Agama Islam Negeri Pekalongan, Indonesia \\ m.minanur.rohman@iainpekalongan.ac.id

\begin{tabular}{|l|l|l|}
\hline \multicolumn{2}{|c|}{ DOI 10.32505/jurnal at-tibyan.v5i2.1874 } \\
\hline Submitted: 15-08-2020 & Revised: 13-10-2020 & Accepted: 26-10-2020 \\
\hline
\end{tabular}

\begin{abstract}
This research tries to raise the interpretation of al-Qusyairi about jihad verses in the Latāif al-Isyārāt. Through content analyctical method, the writer reveals how the substance and the method of interpretation about jihad verses in the Latāif al-Isyārāt and their significance for the definition of deradicalize the understanding of religious texts. The view of al-Qusyairi against jihad can be concluded into two points. Those are peaceful jihad and armed jihad. The significance of jihad verses in the lathaif al-Isyarat can be seen from the aspect of method and substance. From the aspects of the method, the view of al-Qusyairi becomes important because it has offered an open meaning model, contextual, possible solution, and not one direction. From the substance aspect, al-Qusyairi's view of the verses of jihad confirms that jihad is not revolutionary and radical. The view is quite important to inform the public that the jihad is not only war and violence.
\end{abstract}

Keywords: De-Radicalization, Jihad verses, al-Qusyairi, Latāi if al-Isyārāt.

\begin{abstract}
Abstrak
Penelitian ini mencoba mengangkat penafsiran al-Qusyairi tentang ayat-ayat jihad dalam Lațāif al-Isyārāt. Melalui metode analisis konten, penulis mengungkap bagaimana substansi dan metode penafsiran ayat-ayat jihad dalam Latāif al-Isyārāt dan signifikansinya bagi upaya deradikalisasi pemahaman teks-teks keagamaan. Pandangan al-Qusyairi atas jihad dapat disimpulkan menjadi dua poin. Itu adalah jihad damai dan jihad bersenjata. Makna ayat-ayat jihad dalam Latăîf al-Isyärät dapat dilihat dari aspek metode dan substansinya. Dari aspek metodenya, pandangan al-Qusyairi menjadi penting karena menawarkan model makna yang terbuka, kontekstual, solusi yang mungkin, dan tidak satu arah. Dari aspek substansi, pandangan alQusyairi terhadap ayat-ayat jihad menegaskan bahwa jihad tidak bersifat revolusioner dan radikal. Pandangan tersebut cukup penting untuk menginformasikan kepada masyarakat bahwa jihad bukan hanya perang dan kekerasan.
\end{abstract}

Kata Kunci: Deradikalisasi, ayat-ayat jihad, al-Qusyairi, Lațāif al-Isyārāt

Hak Cipta @ 2020. Dimiliki oleh Penulis, dipublikasikan oleh Jurnal At-Tibyan: Jurnal Ilmu Alqur'an dan Tafsir.

Artikel dengan akses terbuka. Lisenci: CC-BY
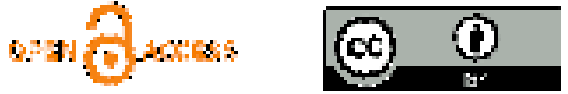


\section{Pendahuluan}

Salah satu faktor sikap radikal dalam beragama adalah kecenderungan memahami al-Qur'an secara tekstual, dangkal dan parsial sehingga acapkali melahirkan perilaku yang terkesan anarkis, intoleran dan destruktif. ${ }^{1}$ Dalam penafsiran ayat-ayat jihad misalnya, yang sering disalahpahami identik dengan terorisme dan fanatisme buta yang sering dipahami sebagai pemaksaan bahkan penyerangan terhadap kelompok yang tidak sefaham. Oleh sebab itu, guna mengembangkan dan mengimplementasikan penafsiran jihad damai, gagasan tentang deradikalisasi penafsiran al-Qur'an perlu mendapat perhatian tersendiri. Jika memang praktik radikalisasi dipengaruhi oleh ideologi radikal, maka harus dilawan dengan deradikalisasi teologi, meminjam istilah al-Qardhawi al-afkār lā tuqawwam illā bi al-afkār (pemikiran hanya bisa dikoreksi dengan pemikiran). ${ }^{2}$

Salah satu pembacaan yang mengartikulasikan makna jihad damai yaitu cara baca kaum sufi. ${ }^{3}$ Al-Qusyairi (w.465 H/1073 M), sebagai salah seorang ahli tasawuf, dikenal sebagai sufi moderat abad V H, pengikut teologi Asy'ari dan fikih Syafi'i. ${ }^{4}$ AlQusyairi dikenal sebagai orang yang berjasa dalam menyelaraskan syari'at dengan tasawuf serta mengembalikan mistisime pada kerangka al-Quran dan al-Hadis. ${ }^{5}$ Dalam hal ini, menarik untuk menelusuri penafsiran Al-Qusyairi tentang ayat-ayat jihad dalam Latäif al-Isyärät, guna menumbuhkan pembacaan al-Quran yang kontekstual serta jauh dari kesan radikal. Berangkat dari latar tersebut, permasalahan yang muncul adalah bagaimana substansi penafsiran ayat jihad dalam Latäif al-Isyārät dan bagaimana signifikansinya bagi upaya deradikalisasi keagamaan saat ini.

Diskursus penelitian tentang al-Qusyairi sudah banyak dilakukan oleh para ahli. Penelitian tentang al-Qusyairi yang spesifik mengangkat kitab Latäif al-Isyārăt diantaranya: Pertama, disertasi doktoral Abdul Munir pada tahun 2009 berjudul Penafsiran Imam Qusyairi dalam Latāif al-Isyārat (Studi tentang Metode Penafsiran dan Aplikasinya). Kedua, disertasi Arsyad Abrar pada tahun 2015 berjudul

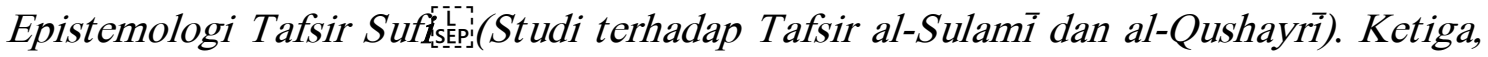
disertasi Habibi al-Amin pada tahun 2016 berjudul Emosi Sufistik Dalam Tafsir Ishari: Studi atas Tafsir Latāif al-Ishärāt Karya al-Qushairi. Melihat penelitian sebelumnya, dapat disimpulkan bahwa penelitian ini berbeda dari penelitian sebelumnya. Penelitian berupaya menampilkan tafsir atas ayat-ayat jihad dalam Latäif al-Isyārät serta signifikansi penafsirannya.

\footnotetext{
${ }^{1}$ Nasaruddin Umar, Deradikalisasi Pemahaman al-Quran dan Hadis, (Jakarta: Elek Media Komputindo, 2014), 2. Lihat juga Yusuf Al-Qardhawi, al-Ṣaḥwah al-Islāmiyyah Baina al-Juhüd wa alTatarruf (Kairo: Bank at-Taqwa, 1989), 59-67.

${ }^{2}$ Al-Qardhawi, Zāhirah al-Guluw fi Takfir, (Mesir: Maktabah Wahbiyyah, 1990), 90

${ }^{3}$ Zakiyudin Baidhawy, Konsep Jihad dan Mujahid Damai, (Jakarta: Kemenag RI, 2012), 95.

${ }^{4}$ Ibrahim Basyuni pengantar Lataif al-Isyārat oleh Al-Qusyairi,(Mesir: al-Hayyah al-Misriyyah alĀmmah li al-Kitāb, 1971), 11.

${ }^{5}$ Amin Syukur dan Masyharuddin, Intelektualisme Tasawuf (Studi Intelektualisme tasawuf alGhazali), (Yogyakarta: Pustaka Pelajar, 2002), 26. M. Solihin, Rosihon Anwar, Ilmu Tasawuf (Bandung: Pustaka Setia, 2008), 131.
} 
Metode analisis data yang digunakan dalam penelitian ini adalah analisis isi (Content Analysis). Dalam analisis ini, penulis menggunakan pendekatan interpretasi. ${ }^{6}$ Pendekatan ini bertujuan menyelami pemikiran al-Qusyairi terhadap ayat-ayat jihad. Penelitian ini merupakan penelitian kepustakaan (literary research). Sumber primernya adalah Lațäif al-Isyārät karya al-Qusyairi. Sedang sumber sekundernya adalah kitabkitab tafsir, kitab-kitab ilmu-ilmu al-Qur'an, dan karya-karya tokoh lain yang mengkaji kehidupan dan ajaran al-Qusyairi.

Sistematika artikel yang akan disajikan oleh penulis adalah: Pertama, biografi alQusyairi dan gambaran singkat Latäif al-Ishärät. Kedua, penulis berupaya menghimpun tafsir ayat-ayat jihad dalam lataif al-isyarat. Kemudian akan diklasifikasikan berdasarkan makna jihad, tujuan jihad, dan etika jihad. Dalam hal ini, penyusun berupaya memahami penafsiran al-Qusyairi tentang ayat-ayat jihad. Hal tersebut dikonstruksi menjadi rangkaian pemaknaan utuh al-Qusyairi tentang konsep jihad. Ketiga, melakukan analisis yang lebih mendalam terhadap metodologi penafsiran alQusyairi terhadap ayat-ayat jihad. Bagian ini juga akan menjelaskan signifikansi penafsiran al-Qusyairi bagi upaya deradikalisasi pemaknaan teks keagamaan di Indonesia saat ini.

\section{Al-Qusyairi dan Lațāif al-Isyārāt}

\section{Biografi, Aktifitas Keilmuan dan Latar Belakang Kehidupan}

Nama lengkap al-Qusyairi adalah Abū al-Qāsim Abd al-Karìm bin Hawāzin bin Abd Mālik bin Ṭalḥah bin Muhammad al-Istiwāi' al-Qusyairi an-Naisābūri As-Syāfí'i. ${ }^{7}$ Ia lahir di kota IstiwāI, kawasan Naisābūr, Iran timur laut, pada bulan Rabī'ul Awal tahun 376 H/986 M. Dari pihak ayahnya, Ia adalah keturunan Bani Qusyayr, salah satu suku Arab yang tinggal di Khurasan. Dari jalur Ibunya, ia adalah keturunan Bani Salam, yang juga adalah salah satu suku Arab.

Keluarga al-Qusyairi tampaknya berkecukupan dan terpelajar. ${ }^{8}$ Hal ini terlihat bahwa ia memperoleh pendidikan yang baik di bawah bimbingan Abū al-Qāsim alAlimani, guru serta kerabat keluarga al-Qusyairi. Kepada al-Alimani, ia belajar bahasa dan sastra Arab. Selanjutnya, al-Qusyairi melakukan perjalanan intelektualnya ke Naisābur. Di kota tersebut, dia mempelajari pengolahan administrasi keuangan. Hal ini merupakan bentuk nyata dalam mewujudkan cita-citanya yaitu meringankan beban masyarakat, yang pada saat itu rakyat dibebani pungutan pajak. ${ }^{9}$

Setelah beberapa saat mempelajari akutansi, ia mulai mempelajari fiqh, tafsirhadis, teologi (kalam), tata bahasa Arab (nahwu dan șaraf), dan juga tasawuf. Sekalipun al-Qusyairi mempelajari semua ilmu tersebut, tasawuf menarik perhatian

\footnotetext{
${ }^{6}$ Anton Bakker dan Achmad Charis Zubair, Metodologi Penelitian Filsafat, (Yogyakarta, Kanisius, 1990), 63

${ }^{7}$ Hamid Algar, Principles at Sufisme (Berkeley: Mizan Press, 1990), I

${ }^{8}$ Ibrahim Basyuni pengantar Lataif al-Isyārat oleh Al-Qusyairi,(Mesir: al-Hayyah al-Misriyyah alĀmmah li al-Kitāb, 1971), 8.

${ }^{9}$ Hamid Algar, Principles at Sufisme (Berkeley: Mizan Press, 1990) , 4.
} 
dan banyak menyita waktunya. ${ }^{10}$ Dalam perkembangan selanjutnya, ketika terjadi peralihan kekuasaan, sekalipun pada awalnya al-Qusyairi mempunyai hubungan yang baik dengan penguasa Seljuk, Rukn al-Dunyā wa al-Din Tughril, kedudukan alQusyairi mulai terusik sebab kebijakan perdana menteri 'Amid al-Mulk Abū Nașr alKunduri, seorang penganut mazhab Hanafiyyah dan beraliran teologi Mu’tazilah yang kukuh. ${ }^{11}$ Selama masa jabatan al-Kunduri inilah, Naisabur juga di wilayah-wilayah lain terjadi mihnah dan fanatisme kelompok. Kelompok Asy'ariyah dan Syafi'iyyah mendapat teror dari al-Kunduri. Melihat kondisi seperti ini, al-Qusyairi mengeluarkan fatwa (436 H/1044 M) yang berisikan bahwa pandangan-pandangan al-Asy'ari sepenuhnya sesuai dengan al-Quran dan Hadis.

Sebab masalah tidak kunjung selesai, al-Qusyairi pada tahun $446 \mathrm{H} / 1054 \mathrm{M}$ menulis surat terbuka kepada para 'ulama di dunia muslim. Surat ini mengeluhkan teror yang dialami Ahl al-Sunnah saat itu. Surat-surat ini kemudian dibukukan dalam sebuah karangan Syīkāyah Ahl al-Sunnah bi Hikāyah mā nā lahum min al-Mị̣nah. Berkaitan dengan surat inilah akhirnya al-Qusyairi dipenjarakan selama sebulan lebih. Namun pemenjaraan berlangsung singkat, karena Abu Sahl, seorang pemimpin mazhab Syāfi' 'i di Naisabur, membela al-Qusyairi dan berhasil membebaskannya. ${ }^{12}$

Al-Qusyairi dikenal masyhur berkat al-Risālah-nya. Buku ini dimaksudkan sebagai wejangan kepada kaum sufi yang sezaman dengannya, dimana saat itu muncul kelompok sufi yang membebaskan diri mereka dari kewajiban melaksanakan syari'at. Tujuan al-Qusyairi adalah menangkal pengaruh mereka dengan menyuguhkan argumen komprehensif tentang kehidupan, ajaran dan praktik para tokoh awal paling otoritatif, yang musti diteladani oleh kaum sufi. Al-Qusyairi juga berikhtiyar menegaskan kepada seluruh pembaca kelayakan praktik-praktik sufi yang sejalan dan identik dengan ajaran kaum Asy'ariy. ${ }^{13}$

Hal tersebut ditegaskan oleh al-Ghazali dalam kitabnya Minhājul Ābidin. ${ }^{14}$ Di sisi lain, Ibn al-Sam'ani juga mengatakan bahwa al-Qusyairi secara sempurna telah mengkompromikan antara syari'at dan hakikat. ${ }^{15}$ Oleh karena itu, Fazlur Rahman berpendapat bahwa al-Qusyairi adalah seorang tokoh sufi yang berjasa dalam memperjuangkan dan menjaga ortodoksi melalui karyanya Risālah al-Qusyairiyyah yang merupakan sintesa antara sufisme dan teologi ortodok. ${ }^{16}$ Dapat disimpulkan, bahwa Al-Qusyairi juga pembela paling tangguh dalam menentang doktrin aliran-aliran Mu’tazilah, Karamiyyah, Mujassimah dan Syi’ah.

\footnotetext{
${ }^{10}$ Zuraiq dan Al-Baltahji, Muallif al-Kitab, 9.

11 Sayyed Hossein Nasr (dkk), Warisan Sufi “ Sufisme Persia Klasik dari Permulaan Hingga Rumi (700-1300), terj. Gafna Raizha Wahyudi (Yogyakarta: Pustaka Sufi, 2002), 204.

12 Ibrahim Basyuni, "Madkhal" dalam al-Qusyairi, Latāîf al-Isyārāt, Jilid I ( Kairo: al-Hayyah alMisriyyah al-'Ammah li al-Kitāb: Cet II:1981), 13.

${ }^{13}$ Hamid Algar, Principles at Sufisme (Berkeley: Mizan Press, 1990), xi.

${ }^{14}$ Aboebakar Atjeh, Pengantar Sejarah Sufi \& Tasawwuf(Solo : CV.Ramadhani : 1984), cet.2, 274.

${ }^{15}$ As-Suyuti, Tabaqāt al-Mufassirin, (Kairo: Maktabah Wahbah, t.th), 61.

${ }^{16}$ Fazlur Rahman, Islam, (Chicago and London: University of Chicago Press, 1979), 50.
} 


\section{Lațāif al-Isyārāt: Sejarah, Latar Belakang Dan Metode}

Al-Qusyairi mempunyai dua produk tafsir, yaitu al-Taisir fi al-Tafsir dan Latäif al-Isyārät. Al-Taisìr fi al-Tafsìr ditulis sebelum perjumpaannya dengan tasawuf, tepatnya pada tahun $410 \mathrm{H}$. Karya berangkat dari analisis bahasa, nạ̣wu, șaraf dan qirāat serta asbāb al-nuzūl nya. Didalamnya juga disebutkan jumlah ayat dalam surat tersebut dan beberapa kisah isräiliyat. Jalaludin Al-Suyuti mengatakan bahwa kitab tafsir susunan al-Qusyairi merupakan salah satu kitab tafsir yang bagus dan jelas. ${ }^{17}$

Karya yang kedua, Latăîf al-Isyārät, merupakan kitab tafsir dengan corak sufistik yang kental, sebagai hasil dari taqarrub dan mujāhadah-nya kepada Allah swt. Kitab Lațāif al-Isyārāt ini sering dianggap sebagai kitab tafsir sufi isyāri akhlaqi terbesar. Banyak ulama memuji kedalaman intuisi dan kematangan spiritual Qusyairi dalam menghayatu Al-Qur'an. Bahkan, menurut Ibn al-Qayyim, kitab ini lebih fenomenal daripada al-Risālah-nya. ${ }^{18}$ Kitab tafsir ini, meski bukan yang pertama, merupakan salah satu kitab tafsir terbaik. Diantara sekian kitab tafsir yang mempunyai corak sufistik, mayoritas mendapat kriti sebab adanya penyimpangan dalam penafsirannya. Sedangkan kitab Latäif al-Isyārät termasuk salah satu tafsir yang dinilai tidak menyimpang dari syarat yang ditentukan ulama. ${ }^{19}$

Di dalam pengantarnya, Ibrāhīm Basuni menjelaskan bahwa al-Qusyairi memberi judul kitab tafsirnya dengan Latāif al-Isyārāt tanpa adanya tambahan apapun. Hal ini dalam rangka meluruskan pendapat sementara orang yang menyebutnya dengan nama Lațāif al-Isyārāt Fì Haqāiq al-Ibārāt. Nama Latāîf al-Isyārāt merujuk diktum terkenal Imam Ja'far al- Șidiq (w.148 H/756 M) yang mengelompokkan makna dalam al-Qur'an menjadi empat tingkatan makna. Pertama, makna Ibārah yang dialamatkan kepada kaum mukmin awam. Kedua, makna Isyärah yang hanya bisa diakses oleh kaum gnostik dikalangan kaum mukmin. Ketiga, makna Latāif yang dialamatkan kepada para wali. Keempat, makna Haqāiq (hakikat-hakikat) yang hanya dipahami oleh para nabi. ${ }^{20}$ Pemilihan nama tersebut menegaskan bahwa al-Qusyairi tidak mendiskusikan makna ibärah dalam Lațäif al-Isyārāt, karena dia telah membahasnya dalam kitab tafsir lainnya. Tingkat makna Isyārah dan Latāif -lah yang dipaparkan dengan prosa lirik yang jelas tanpa abai atas makna literal ayat itu sendiri.

Penafsiran al-Qusyairi terhadap ayat-ayat al-Qur' an menggunakan metode Ijmāli dengan keterangan tambahan secukupnya. Al-Qusyairi menyebut metodenya sebagai al-iqlāl (metode ringkas). Al-Qusyairi, sebagaimana dipaparkan dalam mukaddimah, menggunakan metode al-iqlāl untuk menghindari pembicaraan yang terlalu panjang dalam menafsirkan al-Qur'an sehingga tidak membosankan para pembaca. ${ }^{21}$

\footnotetext{
${ }^{17}$ As-Suyuți, Ṭabaqāt al-Mufassiriñ, (Kairo: Maktabah Wahbah), 61. Ḥaji Khalifah, Kasy al-Ẓunūn, (Beirut: Dar al-Kitab al-'Arabiy, t.th), 519

${ }^{18}$ Ibn al-Qayyim, Talbis Iblis, (Beirut: Dar al-Kitab al-‘Arabiy, t.th), 165.

${ }^{19}$ Ibrahim Basyuni pengantar Lataif al-Isyärat oleh Al-Qusyairi,(Mesir: al-Hayyah al-Misriyyah alĀmmah li al-Kitāb, 1971), 8.

${ }^{20}$ Hamid Algar, Principles at Sufisme (Berkeley: Mizan Press, 1990), xi.

${ }^{21}$ Al-Qusyairi, Lațaif al-Isyārāt, 5.
} 


\section{Penafsiran Ayat-Ayat Jihad dalam Lațāif al-Isyārāt}

Term jihad disebutkan dalam al-Qur'an sebanyak 41 kali. Kata al-juhd hanya dijumpai sekali di dalam al-Qur'an yaitu pada QS. al-Taubah :79. Kata al-jahd ditemukan lima kali, masing-masing dalam QS al-Māidah ayat 53, al-An'ām ayat 109, al-Naḥl ayat 38, al-Nūr ayat 53, dan Fātir ayat $42{ }^{22}$ Kata yang terdiri dari huruf $j-h-d$, menurut Ibnu Faris (w. 395 H) dalam bukunya Mu'jam Al-Maqāyis Al-Lughah, pada awalnya mengandung arti kesulitan atau kesukaran dan yang mirip dengannya". Sebagian pendapat mengatakan bahwa jihad berasal dari akar kata juhd yang berarti "kemampuan". Ini karena jihad menuntut kemampuan, dan harus dilakukan sebesar kemampuan. ${ }^{23}$ Para pakar membedakan antara juhd yang berarti kemampuan (täqah) dan jahd berarti rintangan (masyaqqah). ${ }^{24}$ Dari pengertian tersebut, jelas sekali bahwa term jihad memiliki makna yang luas. Al-Qusyairi menjelaskan bahwa jihad tidak hanya memiliki makna perang, tetapi maknanya mencakup jihad fisik dan jihad nonfisik. Oleh karenanya, pada pembahasan kali ini dapat diklasifikasikan dua kelompok besar, yaitu makna jihad damai (peaceful jihad) dan makna jihad bersenjata (jihad army).

\section{Jihad Damai (Peaceful Jihad)}

Al-Qusyairi menjelaskan bahwa makna jihad sangatlah luas, hal ini dijelaskan ketika ia menafsirkan QS. al-Ḥajj: 78

$$
\text { وَجَاهِدُوا فِي اللَّهِ حَقَّ نجهَادِهِ ....الاية }
$$

Terjemah: "Dan berjihadlah kamu pada jalan Allah dengan jihad yang sebenarbenarnya." 25

Al-Qusyairi menjelaskan bahwa jihad yang sebenar-benarnya adalah sesuatu yang sesuai dengan kemampuan, konteks waktu dan kelas sosial, jika bertentangan maka hal itu bukanlah jihad. Oleh karenanya, al-Qusyairi tidak membatasi pengertian jihad secara sempit, ia menjelaskan bahwa jihad ada bermacam-macam, yaitu jihad dengan jiwa, hati dan harta. ${ }^{26}$

Pemaknaan seperti tersebut sejalan dengan pendapat pakar al-Qur'an al-Raghib al-Isfahani, dalam Mu'jam Mufradāt Al-Fäzh Al-Qur'ān. Bagi al-Asfihani, Jihad terdiri dari tiga macam: (1) menghadapi musuh yang nyata, (2) menghadapi setan, dan (3) menghadapi nafsu yang terdapat dalam diri masing-masing. ${ }^{27}$ Al-Isfahani mendasarkan pendapatnya berdasarkan ayat tersebut.

${ }^{22}$ Muhammad Fuad 'Abd. Al- Baqiy, al-Mu'jam al- Mufahras li Alfāz al Quran al- Karìm, (Beirut: Dār al- Fikr 1992), 232-233

${ }^{23}$ Abu al-Husain Ahmad ibn Faris ibn Zakariya, Mu'jam Maqāyis al-Lugah, Jus. 1 (Beirut: Dār al Fikr, 1994), 487 lihat juga Louis Mahfud al- Munjid fì al- Lugah.(Cet. XVIII, Beirut: Dār al- Maghrib, 1984), 106.

${ }^{24}$ Ibnu Mandzur, Lisān al- 'Arab, Jilid I (Beirut: Dār al - Lisān 'Arab, t.th), 520

${ }^{25}$ Q.S. Al-Hajj [22]:78

${ }^{26}$ Al-Qusyairi, Lațäif al-Isyārāt, vol 2, h. 564

${ }^{27}$ Al-Raghib Al-Isfahani, Mu'jam Mufradāt Al-Fāzh Al-Qur'an, (Beirut: Dār al- Fikr 1992), h. 198 
Bagi al-Qusyairi, perintah jihad tidak selalu terkait dengan peperangan fisik, tetapi juga bermakna etika personal dan spiritual. Hal itu dijelaskan oleh al-Qusyairi dalam penafsiran QS. al-Anfāl: 41

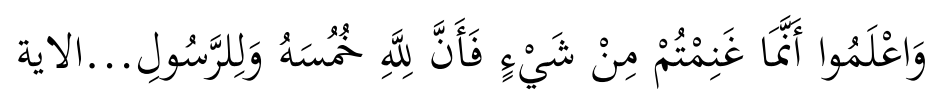

Terjemah: "Ketahuilah, sesungguhnya apa saja yang dapat kamu peroleh sebagai rampasan perang, maka sesungguhnya seperlima untuk Allah, Rasul." 28

Al-Qusyairi, ketika mengomentari ayat tersebut, mengklasifikasikan jihad menjadi dua kelompok, yaitu jihad asgar (perang) dan jihad akbar (melawan nafsu). Orang yang menang dalam berperang (jihad ashghar) akan mendapatkan harta rampasan (ganimah). Begitu pula ketika jihad akbar (melawan nafsu), jika menang akan mendapat ghanimah yaitu menguasai diri yang dulu dikuasai hawa nafsu dan syetan. $^{29}$

Penafsiran tersebut sejalan dengan sabda Rasulullah Saw, ketika baru saja kembali dari medan pertempuran.

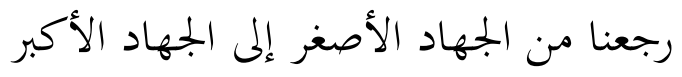

Terjemah: "Kita kembali dari jihad terkecil menuju jihad terbesar, yakni jihad melawan hawa nafsu."

Penafsiran al-Qusyairi tersebut juga sejalan dengan sabda Rasul saw:

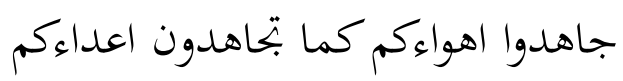

"Terjemah:"Berjihadlah menghadapi nafsumu sebagaimana engkau berjihad menghadapi musuhmu."

Mayoritas ayat-ayat yang berbicara tentang jihad tidak menyebutkan objek yang harus dihadapi. Oleh karenanya, tidak bijak jika membatasi objek hanya kepada orang kafir dan munafik saja karena dalam ayat-ayat lain disebutkan musuh-musuh yang dapat menjerumuskan manusia dalam kubang kejahatan, yaitu setan dan nafsu manusia sendiri. Jelaslah, jihad yang paling utama adalah jihad personal, sebagai penguasaan diri dari godaan setan, dan hawa nafsu. Al-Qur'an juga menegaskan bahwa keduanya pun harus dihadapi dengan perjuangan, sebagaimana firman-Nya dalam QS. AlBaqarah: 168 dan QS. Al-Qașaṣ : 50.

\section{Jihad Bersenjata (Army Jihad)}

Selain mengkaji jihad personal, Al-Qusyairi tidak menafikan kajian tentang jihad dalam artian perang. Setidaknya, ia menitikberatkan pada cakupan tujuan jihad dan etika jihad. Oleh karenanya, ulasan-ulasan berikut berfokus pada dua tema tersebut.

\footnotetext{
${ }^{28}$ Q.S.Al-Anfal [8]: 41

${ }^{29}$ Al-Qusyairi, Lațāif al-Isyārāt, 626.
} 


\section{Tujuan Jihad}

Al-Qusyairi, dalam Lațäif al-Isyārät, menjelaskan bahwa jihad dilakukan apabila mereka menentang setelah dijelaskan hujjah (argumen/bukti). Hal ini tampak ketika alQusyairi menafsirkan QS. At-Taubah:73

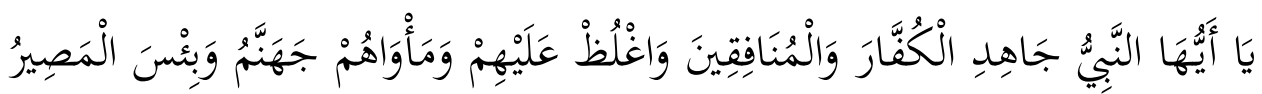

Terjemah: "Hai Nabi, perangilah orang-orang kafir dan orang-orang munafik dan bersikap keraslah terhadap mereka. Tempat mereka adalah jahannam dan itu adalah seburuk-buruknya tempat kembali." ${ }^{30}$

Al-Qusyairi menjelaskan bahwa tujuan utama diutusnya Rasul adalah menyeru semua makhluk kepada perbaikan akhlak. Ia menjelaskan mengapa ayat tersebut memerintahkan bersikap keras, padahal Allah memerintahkan kepada Nabi Musa untuk berkata lemah lembut ketika hendak menyeru Fir'aun. ${ }^{31}$ Al-Qusyairi mencoba mengkompromikan ayat perintah perang yang tampak bertentangan ayat-ayat yang mengindikasikan larangan melakukan perang secara fisik sebelum hijrah. Ayat yang menjelaskan larangan tersebut adalah (QS. Fuṣsilat: 34), (QS. Al-Māidah: 13), (QS. An-Nahl: 125 dan 82), (QS. Al-Furqān: 63), (QS. Al-Ghāsyiyah: 22), (QS. Qāf: 45), (QS. Al-Jātsiyah:14). ${ }^{32}$

Oleh karena itu, Al-Qusyairi menjelaskan bahwa Nabi berdakwah dengan lemah lembut, tetapi ketika mereka berbuat kezaliman maka turunlah perintah untuk memerangi mereka. Jadi sebab turunnya perintah jihad adalah membela dan membebaskan orang-orang yang tertindas. Hal ini dikuatkan penafsiran al-Qusyairi atas QS. Al-Anfāl :39

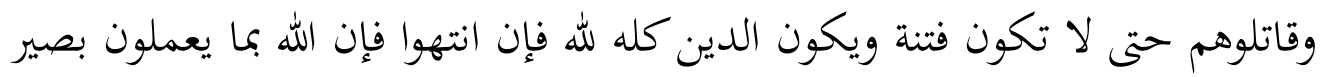

Terjemah: "Dan perangilah mereka, supaya jangan ada fitnah dan supaya agama itu semata-mata untuk Allah. Jika mereka berhenti (dari kekafiran), maka sesungguhnya Allah Maha Melihat apa yang mereka kerjakan."33

Al-Qusyairi menjelaskan bahwa Allah memerintahkan memerangi orang-orang kafir sehingga kepedihan kaum muslim sirna. Berangkat dari ayat tersebut, Jihad, bagi al-Qusyairi, bertujuan agar orang muslim merasa aman dari bahaya orang kafir dan menghilangkan fitnah secara menyeluruh. ${ }^{34}$ Peperangan sendiri pada hakikatnya tidak dikehendaki oleh Islam. Al-Qur'an menyatakan dalam QS. al-Baqarah: 216.

Pada bagian lain, al-Qusyairi menegaskan hal tersebut ketika menafsirkan QS. alHajj: $39-40$

\footnotetext{
${ }^{30}$ Q.S. Taubah [9]: 73

${ }^{31}$ Al-Qusyairi, Latāîif al-Isyārāt, vol. 2, 46.

${ }^{32}$ Al-Zuhailiy, Tafsìr al-Munir, vol I, (Beirut: Dar al-Fikr al-Mu'ashir, 1998), 178.

${ }^{33}$ Q.S.Al-Anfal [8]: 39

${ }^{34}$ Al-Qusyairi, Lațäif al-Isyārāt vol 2, 625.
} 


$$
\text { اذن للذين يقاتلون بأفم ظلموا. وإن الله على نصرهم لقدير }
$$

Terjemah: "Telah diizinkan (berperang) bagi orang-orang yang diperangi, karena sesungguhnya mereka telah dianiaya." 35

Al-Qusyairi menjelaskan bahwa perang diizinkan ketika ditimpa bahaya atau penganiayaan fisik dari musuh-musuh, dimana berlaku ketidak adilan atau orang lain yang berkuasa dan zalim. ${ }^{36}$ Penjelasan tersebut menjelaskan bahwa alasan dari perintah perang yaitu adanya kezaliman yang dilakukan oleh orang kafir terhadap kaum Muslim. Penafsiran tersebut sejalan dengan sejarah bahwa peperangan yang terjadi di zaman Rasul adalah gambaran kondisi darurat. ${ }^{37}$ Semasa Nabi Muhammad saw hidup, peperangan terjadi sebanyak $17 \mathrm{kali}$, ada juga yang menyebutnya 19 kali; 8 diantaranya yang diikuti Nabi. Namun, perang yang dilakukan Nabi adalah untuk perdamaian. ${ }^{38}$ Peperangan dalam Islam diizinkan hanya dalam kondisi tertentu, misal motivasi membela jiwa, harga diri, harta, negara dan melawan intimidasi terhadap orang yang ingin masuk islam.

Al-Qusyairi menegaskan bahwa perintah adanya perang sebab kezaliman mereka, hal itu dijelaskan ketika ia menafsirkan QS. al-Ḥujurāt: 9

$$
\text { فَإِان بَغَتْ إِحْدَاهُمَا عَلَى الأُخْرَى فقاتلوا التي تبغي....الاية }
$$

Terjemah: "Tapi kalau yang satu melanggar perjanjian terhadap yang lain, hendaklah yang melanggar perjanjian itu kamu perangi." 39

Al-Qusyairi menjelaskan bahwa ayat tersebut menjelaskan kewajiban menolong orang yang tertindas. Kemudian al-Qusyairi mengambil ibrah dari ayat tersebut tentang kewajiban jihad sebagai pengendalian nafsu karena telah menzalimi hati dengan mengajak kepada syahwat. ${ }^{40}$

Pengendalian nafsu ini pada akhirnya bertujuan agar salik tidak terjerumus dalam golongan orang yang lalai. Hal ini sebagaimana pembacaan al-Qusyairi atas QS. alBaqarah: 217

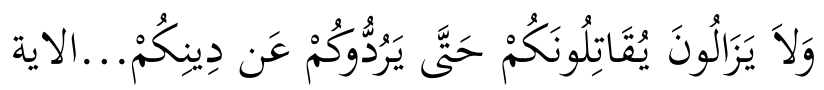

Terjemah: "Mereka tidak henti-hentinya memerangi kamu sampai mereka (dapat) mengembalikan kamu dari agamamu (kepada kekafiran), seandainya mereka sanggup. $" 41$

Al-Qusyairi menjelaskan bahwa ayat tersebut mengisyaratkan untuk menentang ajakan orang-orang yang lalai. Al-Qusyairi tidak tekstual dalam memahami ayat

\footnotetext{
${ }^{35}$ Q.S. Al-Hajj [22]: 39-40

${ }^{36}$ Al-Qusyairi, Latäif al-Isyārāt vol 2, 548.

${ }^{37}$ Sayyid Sabiq, Fiqh al-Sunnah, vol 3, (Beirut: Dar al-Fikr, 1983), 22.

${ }^{38}$ Ibnu Katsir, al-Bidāyah wa al-Nihāyah, vol 2, (Kairo: Dar al-Hadiṣ, 1992), 278.

${ }^{39}$ Q.S. Al-Hujarat [49]:9

${ }^{40}$ Al-Qusyairi, Lațāif al-Isyārāt, 440.

${ }^{41}$ Q.S. Al-Baqarah [2]: 217
} 
tersebut, tetapi mengambil isyarat dari ayat tersebut, sehingga tidak membatasi pada orang kafir saja tetapi siapa saja yang mendatangimu dengan tujuan memalingkanmu kepada kelalaian. $^{42}$

Al-Qusyairi membaca ayat-ayat jihad dengan cara mengkompromikan ayat perintah jihad yang terkesan bertentangan. Al-Qusyairi juga mengambil isyarat dan 'ibrah dari ayat-ayat tersebut. Menurut al-Qusyairi, izin memerangi kaum kafir bukan karena kekufuran atau keengganan mereka memeluk Islam, tetapi karena penganiayaan yang mereka lakukan terhadap hak asasi manusia untuk memeluk agama yang dipercayainya. Oleh karena itu, al-Qusyairi menyimpulkan sebab turunnya perintah jihad adalah membela dan membebaskan orang-orang yang tertindas. Selain memaknai tujuan jihad, al-Qusyairi juga menegaskan etika-etika jihad dalam berbagai pembacaan ayat al-Qur'an.

\section{Etika Jihad}

Betapapun, al-Qusyairi menekankan bahwa Nabi diutus sebagai rahmat bagi seluruh makhluk. Hal ini dijelaskan oleh al-Qusyairi ketika menafsirkan QS. al-Anfā: 61

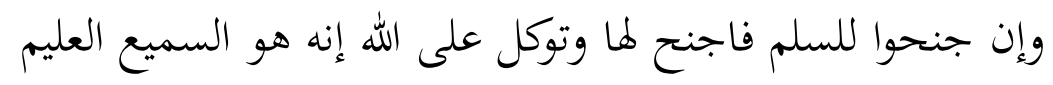

Terjemah: "Dan jika mereka condong kepada perdamaian, maka condonglah kepadanya dan bertawakkallah kepada Allah. Sesungguhnya Dialah Yang Maha Mendengar lagi Maha Mengetahui."43

Al-Qusyairi menjelaskan bahwa Nabi diutus sebagai rahmat dan kasih sayang kepada semua makhluk bahkan dengan orang-orang kafir, sehingga diharapkan kelak mereka akan beriman. ${ }^{44}$ Ayat ini menyebutkan sikap al-Qur'an terhadap peperangan, yaitu upaya untuk menghindari peperangan dan tidak melaksanakan perang kecuali setelah seluruh cara damai ditempuh. Bahkan, al-Qusyairi menegaskan untuk memandang mereka dengan pandangan rahmat. Hal ini dijelaskan al-Qusyairi ketika menjelaskan QS. An-Nisā': 90

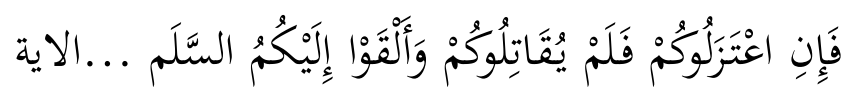

Terjemah: "tetapi jika mereka membiarkan kamu, dan tidak memerangi kamu serta mengemukakan perdamaian kepadamu." 45

Al-Qusyairi menjelaskan bahwa jika memungkinkan bagi umat muslim, maka pandangilah mereka dengan pandangan kasih sayang, sebab perhatian kita itu membekas kepada mereka, jika tidak maka selamatkanlah keadaan mereka. ${ }^{46}$

\footnotetext{
${ }^{42}$ Al-Qusyairi, 176.

${ }^{43}$ Q.S.Al-Anfal [8]: 61

${ }_{44}$ Al-Qusyairi, 636.

${ }^{45}$ Q.S.An-Nisa' [4]: 90

${ }^{46}$ Al-Qusyairi, 353
} 
Salah satu hal yang diajarkan dalam islam dalam berperang yaitu tidak boleh melanggar etika yang dalam bahasa al-Qur'an diistilahkan “wa là ta'tad̄" (dan janganlah melewati batas). Jihad atau peperangan yang diizinkan al-Qur'an hanya unt uk menghindari terjadinya penganiayaan sebagaimana bunyi firman-Nya:

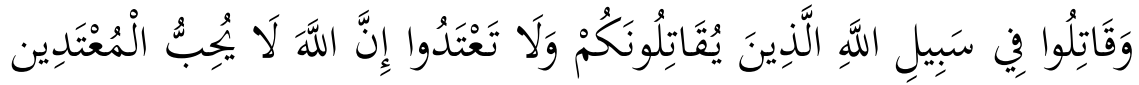

Terjemah: "Perangilah di jalan Allah mereka yang memerangi (kamu) dan jangan melampaui batas, karena sesungguhnya Allah tidak menyukai orang-orang yang melampaui batas." 47

Ayat tersebut menegaskan bahwa kaum Muslim yang melampaui batas ketetapan Allah pun dinilai berbuat zalim, dan atas dasar itu mereka wajar untuk dimusuhi Allah dan kaum Mukmin (yang lain). Ayat tersebut menggunakan padanan kata mufáalah (muqātalah) yaitu dengan menambah huruf alif setelah huruf qaf. Ini adalah qiraah yang disepakati oleh para pakar qiraah, karena kata qătilu menuntut suatu peristiwa dengan saling melakukan perbutatan tersebut, dengan kata lain saling berperang. Hal ini menunjukkan adanya pihak yang memulai peperangan terlebih dahulu, sehingga kedua belah pihak terlibat didalamnya. ${ }^{48}$ Al-Qusyairi menegaskan hal tersebut ketika menafsirkan QS. Muhammad: 4.

$$
\text { فإذا لقيتم الذين كفروا فضرب الرقاب حتى إذا أثخنتموهم فشدوا الوثاق }
$$

Terjemah: "Apabila kamu bertemu dengan orang-orang kafir (di medan perang) maka pancunglah batang leher mereka." 49

Al-Qusyairi menjelaskan jika memperoleh kemenangan maka maafkanlah, dan janganlah berlebihan dalam memusuhi mereka, dan memberi kesempatan kepada orang yang menyesal karena tujuan utama jihad ialah melenyapkan nafsu mereka (bukan pribadinya). ${ }^{50}$ Penafsiran al-Qusyairi tersebut meluruskan tuduhan Mark A. Gabriel tentang eksistensi QS. Muhammad [47] yang disebut juga dengan surah al-Qitāl sebagai landasan untuk mengukuhkan posisi jihad dalam ajaran islam. ${ }^{51}$ Dari beberapa kajian tersebut, dapat meluruskan beberapa stigma yang sangat negatif dari beberapa kajian akademisi Barat.

\section{Metodologi Tafsir Isyari al-Qusyairi}

Setelah sub-bab sebelumnya menjelaskan perihal penafsiran al-Qusyairi terhadap ayat-ayat jihad, maka bagian ini akan menampilkan analisis yang berkaitan dengan nalar tafsir isyari al-Qusyairi. Terkait sikap atas tafsir isyari, setidaknya, ada dua sikap,

\footnotetext{
${ }^{47}$ Q.S. Al-Baqarah [2]: 190

${ }^{48}$ Muhammad Ali al-Shabuny, Rawāi' al-Bayān, Tafsìr Āyāt al-Ahkām min Al-Qur'an, jilid 1, (Beirut: 'Alam Al-Kitab, 1986), 239.

${ }^{49}$ Q.S. Muhammad [47]: 4

${ }^{50}$ Al-Qusyairi, Lațäif al-Isyārāt, 404.

${ }^{51}$ Nasaruddin Umar, Deradikalisasi Pemahaman al-Qur'an dan Hadis, (Jakarta: PT. Elex Media Komputindo, 2014), 119
} 
yaitu: kelompok yang mengafirmasi dan kelompok yang menegasikan keabsahan tafsir isyari.

Kelompok pertama yaitu kelompok yang mengafirmasi keabsahan tafsir isyari. Kalangan ini berpendapat bahwa pemaknaan isyari tidak mengeliminasi tatanan lahir Alquran, namun memberikan nuansa makna berbeda yang justru merupakan makna turunan dari makna literalnya. Al-Ghazali menjelaskan bahwa meskipun kalangan sufi berorientasi pada upaya mengungkap makna spiritual dibalik teks, namun mereka masih menerima makna eksternal teks. Di sisi lain, Schimmel menegaskan bahwa para sufi tidak menampik makna eksternal al-Quran. Bagi para sufi, syariat, sebagai representasi dimensi eksternal al-Quran, merupakan sumber yang darinya capaian spiritual berasal. ${ }^{52}$ Dengan kata lain, kaum sufi tidak terlepas dari tuntutan-tuntutan legal-etis dalam Islam dan formalitas agama. Kaum sufi tidak menanggalkan bentukbentuk ritual agama, namun justru memaknainya secara lebih dalam. Dengan demikian, bagi kelompok ini, tidak ada kontradiksi antara dimensi esoterik dan dimensi eksoterik pada tafsir isyari.

Sikap kedua yaitu mereka yang menegasikan keabsahan tafsir isyari. Ibn Taymiyyah menyamakan takwil isyari dengan takwil batini yang dianggap menolak dan tidak mengimani dimensi lahir al-Quran. Dari kalangan orientalis, pendapat yang sama dilontarkan oleh Nicholson. Menurutnya, kaum sufi, mengadopsi perangkat takwil dari golongan Syi'ah, menjustifikasi ajaran-ajaran mistis mereka dengan cara mentakwilkan al-Quran sesuai dengan kepentingan-kepentingan mereka. Goldziher menegaskan bahwa kaum sufi mengunakan mekanisme interpretasi simbolik sebagai alat justifikasi bagi paham-paham yang sesuai dengan al-Quran dan Sunnah. Secara lebih spesifik, al-Jābiriberpendapat bahwa mekanisme takwil sufi adalah perangkat yang sebenarnya telah digunakan oleh berbagai aliran gnostik. Kaum sufi mengadopsi takwil gnostik yang berasal dari tradisi hellenisme dan filsafat mistik-hermetisme. ${ }^{53}$ Secara ringkas, bagi kelompok ini, tafsir isyari menolak dan menyelisihi dimensi lahir al-Quran. Tafsir Isyari diklaim mengadopsi perangkat takwil dari berbagai tradisi dan pemikiran asing di luar Islam. Pertanyaannya, apakah klaim tersebut tepat? Bagaimana dengan tafsir al-Qusyairi? Apakah metodologi penafsiran al-Qusyairi?

Berbeda dengan kalangan ulama eksoterik yang mendekati teks secara objektif dengan memfokuskan pada aspek historisitas dan linguistik teks, pendekatan alQusyairi merupakan pedekatan personal berdasarkan pengalaman mistis-subjektif, yang sama sekali terlepas dari kerangka rasio. Meminjam analisis Habibi al-Amin, metodologi penafsiran al-Qushairì dalam Latạ̄'if al-Ishārā̄ dipengaruhi oleh unsur emosi sufistik. Dengan kata lain, tafsir al-Qusyairi adalah tafsir ekspresif(at-tafsir bi

\footnotetext{
${ }^{52}$ Sansan Ziaul Haq, "Hermeneutika Sufistik: Telaah Epistemologi Takwil Ibn 'Arabī” Jurnal AtTibyan: Jurnal Ilmu Alqur'an dan Tafsir 4 no. 1, (Juni 2019): 1-25. https://doi.org/10.32505/ tibyan.v4i1.890

${ }^{53} \mathrm{Haq}, 1-25$
} 
al-infi'al). Dalam hal ini, penyingkapan makna al-Quran memiliki relasi erat dengan laku spiritual. ${ }^{54}$

Teks al-Quran, menurut tilikan Massignon dan Nwyia, merupakan titik tolak penyingkapan tafsir isyari para sufi. Gagasan sufistik tidak muncul lebih awal sebelum teks al-Quran, melainkan merupakan hasil dialog antara teks al-Quran dan pengalaman mistikal masing-masing. Pengetahuan Irfan tidak didasarkan atas objek eksternal atau runtutan logis, melainkan dari penghayatan kesufian. ${ }^{55}$ Dialektika antara teks al-Quran dan spiritual berpengaruh sangat besar dalam penyingkapan makna al-Quran. Namun demikian, apakah "ektase hermeuneutis" seorang sufi memperkenankan untuk berlepas dari kendali eksoterisme al-Quran. Dengan kata lain, apakah penafsiran al-Qusyairi menyelisihi teks al-Quran?

Meminjam tilikan Abrar, tafsir al-Quran yang diterapkan oleh al-Qusyairi, selain memiliki dasar yang berasal dari al-Quran dan Sunnah, juga memiliki relasi rasional yang tidak bertentangan dengan al-Quran itu sendiri. Tafsir al-Qusyairi dibangun oleh dualisme tanpa menegasikan satu sama lain, yaitu syariah (eksoterik) dan hakikat (esoterik). ${ }^{56}$ Berdasar hal tersebut, tafsir al-Qusyairi tidak menolak secara mutlak penggunaan zahir ayat, sebaliknya, zahir ayat memberikan pengaruh dalam tafsir alQusyairi.

Jika memperhatikan penafsiran al-Qusyairi atas ayat-ayat jihad, ia lebih sering menempuh metode sufi bi al-isyāri. Selain perspektif sufi, al-Qusyairi juga terkadang menggunakan pendekatan bi al-ma'tsür. Pembacaan al-Qusyairi ini menegaskan relasi tasawuf dan ajaran al-Qur'an-hadis. Oleh karenanya, Muhammad Abduh dan Rasyid Ridha memasukkan Al-Qusyairi kedalam golongan ulama' sufi pembaharu, puritan dan aktivis. ${ }^{57}$ Fazlur Rahman berpendapat bahwa al-Qusyairi adalah seorang tokoh sufi yang berjasa dalam memperjuangkan dan menjaga ortodoksi melalui karyanya Risālah al-Qusyairiyyah yang merupakan sintesa antara sufisme dan teologi ortodok. ${ }^{58}$ Penegasan tersebut menunjukkan bahwa al-Qusyairi tetap mengacu pada otoritas teks. Al-Qusyairi melandasi tradisi teks dengan pendekatan intuisi dan pengalaman langsung (direct exprience) spiritual keagamaan.

Menurut Thaher Ibn Asyur dalam tafsirnya mengemukakan, bahwa tafsir isyary dapat dibenarkan selama isyarat-isyarat yang dikemukakan tidak keluar dari tiga macam isyarat. Pertama, serupa keadaanya dengan apa yang dilukiskan ayat. Kedua, lahir dari prasangka baik dan optimisme. Ketiga, berupa hikmah dan pelajaran. ${ }^{59}$ Jika

\footnotetext{
${ }^{54}$ Habibi Al Amin, Emosi Sufistik Dalam Tafsir Ishārī Studi atas Tafsīr Lațā'if al- Ishārāt Karya alQushairi, Disertasi UIN Syarif Hidayatullah, Jakarta, 2015, 2.

${ }^{55}$ M. Ulil Abshor, "Epistemologi Irfani (Sebuah Tinjauan Kajian Tafsir Sufistik)" Jurnal At-Tibyan: Jurnal Ilmu Alqur'an 'an Tafsir 3 no. 2, (Desember 2018): 249-264. https://doi.org/10.32505/ tibyan.v3i2.649

${ }^{56}$ Arsyad Abrar, Epistemologi Tafsir Sufi (Studi terhadap Tafsir al-Sulamī dan al-Qushayrī), Disertasi UIN Syarif Hidayatullah, Jakarta, 2015, 2.

${ }^{57}$ Rasyid Ridha, Tafsīr al-Manār, vol 11, (Mesir: Maṭba'ah al-Manār, 1349),345.

${ }^{58}$ Fazlur Rahman, Islam, (Chicago and London: University of Chicago Press, 1979), 70.

${ }^{59}$ Lilik Faiqoh, "Unsur-Unsur Isyary Dalam Sebuah Tafsir Nusantara (Telaah Analitis Tafsir Faid alRahman Kiai Sholeh Darat) “ Jurnal At-Tibyan: Jurnal IImu Alqur'an dan Tafsir 3 no. 1, (Juni 2018): 70-
} 
dinilai dari tolak ukur syarat tafsir isyari tersebut, maka tafsir al-Qusyairi termasuk tafsir isyari yang dapat diterima. Tafsir al-Qusyairi, sebagaimana kajian di atas, dinilai memenuhi syarat diterimanya suatu tafsir isyāri karena tidak berlawanan dengan teks primer dan sekunder serta kaidah bahasa Arab. Selain tetap menyandarkan makna baru kepada makna eksoteris, al-Qusyairi juga tidak mengklaim bahwa hanya itu saja tafsir yang dikehendaki Allah. Pembacaannya pun tidak condong pada term dan premis falsafi rumit yang akan menghilangkan makna hidayah dari al-Quran.

Memperhatikan metode dan substansi penafsiran al-Qusyairi terhadap penafsiran atas ayat-ayat jihad dalam Latäif al-Isyārāt, jelas bahwa pemaknaan al-Qusyairi masuk dalam kategori tafsir Isyari $\overline{\bar{i}}$ Akhlaqui. Jika merujuk pada penafsirannya, visi tasawuf alQusyairi berusaha menyelaraskan tasawuf dengan dalil ortodoksi Islam. Al-Qusyairi dengan demikian selalu menghormati prinsip tekstualitas dan tidak menolak makna literal. Makna batin merupakan makna tambahan berdasarkan penyingkapan ilahiyyah, yang bisa dipercaya seturut tidak berseberangan dengan makna literal. Mengingat bahwa takwil al-Qusyairi pada dasarnya selaras dengan eksoterisme al-Quran, pendekatan takwil al-Qusyairi dapat disebut literalisme-spiritual, sebagai relasi dialogis antara makna lahir dengan makna batin.

Berdasarkan elaborasi di atas, dapat disimpulkan bahwa takwil al-Qusyairi merupakan upaya memahami apa yang Allah maksud dalam konstruksi tekstual kitabNya berdasarkan ilhām ilahì, bukan pencerapan atas pelbagai unsur asing dalam pembacaan Alquran. Dengan demikian, makna spiritual selalu merupakan makna derivatif dari makna tekstual, bukan malah menghapus ataupun menggantikannya. Dualisme lahir-batin tersebut merupakan spektrum makna yang saling melengkapi. Implikasi epistemologis seperti ini terlihat jelas pada loyalitas al-Qusyairi terhadap dimensi syariat secara khusus dan sistem dogma Islam secara umum. Dalam konteks takwil al-Qusyari, dialektika antara teks dengan penghayatan jiwa seorang sufi memproduksi signifikansi makna yang mengacu pada hakikat-hakikat spiritual. Namun ketersingkapan makna ini sama sekali tidak berimplikasi terhadap dekonstruksi tatanan tekstual Alquran. Relasi antara teks dengan penghayatan kesufian merupakan hubungan dialektis yang saling memperkaya, bukan saling menegasikan.

\section{Signifikansi Metode dan Subtansi Tafsir Isyari al-Qusyairi Signikansi Metodologi al-Qusyairi}

Betapapun, produk tafsir ikut berperan dalam memberikan warna pemahaman Islam kepada masyarakat. Akar genealogis tersebut meniscayakan rekonstruksi metodologi dalam konteks deradikalisasi pemahaman keagamaan. Secara sederhana, 'deradikalisasi pemahaman tafsir' dalam tulisan ini adalah sebuah upaya memutus mata rantai paradigmatik yang menyebabkan timbulnya konstruksi tafsir yang

90. https://doi.org/10.32505/tibyan.v3i1.479. lihat juga persyaratan lain dalam Ibn al-Qayyim, AtTibyān fì Aqsām al-Qur'ān, (Beirut: Dār al-Ma'rifah), 51, al-Syathibiy, al-Muwāfaqāt, juz 3, 264, alDzahabi, al-Tafsìr, jus 2, 377, al- Zarqani, Manāhil al-'Irfän, (Beirut: Dār al-Fikr), juz 2, 59. 
cenderung radikal, yakni dengan melakukan kritik terhadap metodologi tafsir yang dianggap tidak kompetibel lagi, untuk kemudian dirumuskan metodologi yang dapat menjawab problem kekinian.

Oleh karena itu, sudah saatnya pembacaan tekstual dan skripturalistik didekonstruksi dengan pelbagai pendekatan modern. Pada dasarnya, pemdekatan modern ini mempunyai satu corak, yaitu kontekstualisasi ajaran al-Qur'an dan Sunnah. Fazlur Rahman misalnya, mengapresiasikan ide kontekstualisasi tersebut dengan teori idea moral dan pergerakan ganda. Nasr Hamid Abu Zaid dikenal dengan rekonstruksi ilmu al-Quran yang menekankan pentingnya melakukan reformulasi ta'wil. Kemudian 'Abid al-Jabiri mengembangkan formulasi nalar Arab dengan trilogi paradigmatiknya. $^{60}$

Terlepas dari beberapa kekurangan yang dimiliki oleh pendekatan modern tersebut, prosedur yang ditawarkan sesungguhnya juga banyak ditawarkan oleh ilmu tafsir klasik. ${ }^{61}$ Pendekatan kaum modernis seperti tersebut, tidak begitu populer dalam tradisi pemikiran Islam, bahkan cenderung dihindari dan ditolak sebagai salah satu pendekatan dalam studi Islam, terutama studi teks al-Qur'an.

Hermeneutika misalnya, Machasin menjelaskan beberapa faktor penyebab pendekatan ini tidak begitu populer: Pertama, istilah hermeneutika berasal dari tradisi pemikiran barat. Kedua, di dalam tradisi Islam sendiri sudah ada tradisi memahami teks. Ketiga, ada anggapan bahwa al-Qur'an sudah memberikan pengertian dan penjelasan yang sangat jelas. Keempat; hermeneutika sudah berkembang sedemikian rupa, sehingga tidak hanya berkenaan dengan aturan-aturan penafsiran, melainkan pembicaraan mendalam mengenai hakikat penangkapan pesan dan pemaknaan teks, serta ungkapan-ungkapan kemanusiaan lainnya (analog teks). ${ }^{62}$ Oleh karenanya, dapat disimpulkan bahwa pendekatan kaum sufi lebih populer di kalangan Muslim, dibandingkan dengan pendekatan kaum modernis. Tentu saja hal tersebut berimplikasi pendekatan sufi ini lebih mudah diterima di kalangan kaum Muslim.

Terkait dengan upaya deradikalisasi pemahaman al-Qur'an dan hadis, tafsir isyari nampaknya menjadi pendekatan yang paling tepat dibandingkan model pendekatan modern. Deradikalisasi via tafsir isyari ini diharapkan mampu memberi solusi bagi ketegangan yang terjadi di tengah-tengah isu terorisme yang menyudutkan Islam. Pola pendekatan ini penting dilakukan guna menyingkap makna yang tersembunyi di balik teks. Visi tersebut agar pemahaman keagamaan kembali pada landasan ontologis bahwa Al-Qur'an adalah kitab rahmah yang mendorong umatnya untuk menciptakan masyarakat yang damai (peacefull society) yang saling menghormati, toleran dalam ke-

60 Junaidi Abdillah, "Dekonstruksi Tafsir Ayat-ayat Kekerasan", Jurnal Analisis: Jurnal Studi Keislaman 11 no.1, (Juni 2011):71-90, https://doi.org/10.24042/ajsk.v11i1.611

${ }^{61}$ Muhammad Harfin Zuhdi, "Fundamentalism Dan Upauya Deradikalisasi Pemahaman Al-Quran Dan Hadis", Jurnal RELIGIA 13 no. 1, (April 2010): 81-102

${ }^{62}$ Machasin, "Sumbangan Hermeneutika Terhadap ilmu Tafsir", Jurnal Studi Agama dan Demokrasi Surabaya bekerjasama dengan The Asia Foundation, 5 no.14 (2003): 122-123. 
bhinekaan. Tafsir isyari juga merupakan cara membaca yang melahirkan produk tafsir yang lebih kreatif, produktif dan solutif.

Arah dan wilayah yang menjadi sasaran utama dalam tafsir al-Qusyairi adalah pembenahan akhlak dalam hal ubudiyah kepada Allah. Hal yang penting dalam tafsir al-Qusyairi adalah bagaimana memurnikan tauhid dan terhindar dari perbuatan syirik. Tafsir sufi merupakan refleksi kejiwaan dan memiliki orientasi ketuhanan, sehingga tafsir-tafsir ayat al-Quran selalu dikaitkan dengan ketuhanan, tepatnya menguraikan ekuilibrium relasi manusia, alam dan Tuhan.

Dari sisi metode, tafsir isyari al-Qusyairi menjadi penting karena telah menawarkan model pemaknaan yang terbuka, kontekstual, komprehensif, dan tidak dangkal sehingga dengan metode tersebut melahirkan perilaku yang damai dan toleran. Pemaknaan demikian lebih memungkinkan untuk menerima perubahan sosial dan apresiatif terhadap keragaman, sehingga lebih relevan bagi pergaulan global, serta berdampak positif bagi kehidupan bermasyarakat, berbangsa dan bernegara. Tafsir sufi al-Qusyairi berupaya menghayati al-Qur'an sebagai laku spiritual sehingga metode penafsirannya tidak dipenuhi analisis filosofis yang berlebihan

Berdasar elaborasi di atas, karakter utama dari tafsir isyari al-Qusyairi adalah melahirkan kesan damai dan toleran. Alih-alih memakai ayat untuk menyerang pihak luar (kritik eksterior), al-Qusyairi menghayati ayat-ayat al-Quran sebagai kritik personal (kritik interior), yaitu suatu penarikan ibrah dan hikmah dari ayat, sehingga ayat-ayat al-Quran benar-benar menjadi nilai-nilai spiritual (tarbiyah rūhiyah) bagi pembacanya.

\section{Signifikansi Substansi Jihad al-Qusyairi}

Beberapa pakar telah mendefinisikan makna jihad dan berbagai variannya. Bagi pendiri Ikhwân al-Muslimîn, jihad adalah kewajiban yang berkelanjutan hingga hari kiamat; tingkat terendahnya penolakan keburukan dengan hati dan tertinggi perang di jalan Allah. Di antara keduanya perjuangan dengan lisan, pena dan tangan bertujuan menyatakan kebenaran di depan penguasa yang lalim. Wahbah al-Zuhayli, seorang mufasir dan ulama fikih menulis bahwa jihad ialah mencurahkan daya upaya memerangi orang kafir dengan jiwa, harta dan lisan. ${ }^{63}$ Pemaknaan sebagian pakar tersebut menegaskan konsep jihad yang ofensif-politis. Diantara pelbagai konsep jihad di atas, apa kekhasan konsep jihad al-Qusyairi?

Dari sisi substansi, konsep jihad al-Qusyairi memperlihatkan konsistensinya dalam memperjuangkan nilai-nilai jihad bukan pada tataran formalitas an-sich. Penggalian nilai spiritual pada ayat-ayat jihad menegaskan bahwa jihad bukan hanya sebagai bersifat revolusioner dan radikal (army jihad). Hal ini berbeda dengan konsep jihad Sayyid Qutb sebagai suatu pergerakan untuk memerangi segala bentuk sistem

\footnotetext{
${ }^{63}$ Muhammad Chirzin, "Reaktualisasi Jihad Fi Sabil Allah Dalam Konteks Kekinian Dan Keindonesiaan”, Jurnal Ulumuna, 10 No. 1 (Januari-Juni 2006): 59-80
} 
jahiliyah melalui harakah (pergerakan). ${ }^{64}$ Al-Qusyairi juga memiliki pandangan yang berbeda dengan Qutb. Jika Qutb mengatakan bahwa jihad ini bersifat ofensif, maka bagi al-Qusyairi jihad mengangkat senjata bersifat defensif, yaitu mengangkat senjata sebagai bentuk pertahanan dan perlawanan dari serangan musuh yang menyerang terlebih dahulu.

Jika Qutb memaknai jihad bernuansa "normatif-politis", sedangkan al-Qusyairi "normatif-spiritual". Kesan "politis" dari pemikiran Qutb ini tampak dari bagaimana ia, dengan "jihad" ingin mewujudkan suatu pemerintahan yang menerapkan sistem dan aturan Allah secara total. Adapun pemaknaan al-Qusyairi yang terkesan "normatifspiritualiis" tampak dari penjelasan-penjelasannya yang tidak menafsirkan ayat-ayat jihad hanya berbicara seputar perjuangan bersenjata, tetapi menyangkut persoalan laku individu, hubungan individu dengan Allah, dan aspek-aspek jihad lain seperti ekonomi, intelektual dan seterusnya.

Makna jihad al-Qusyairi ini sejalan dengan konsep jihad Quraish shihab. Jihad alQusyairi, sejalan dengan konsep Quraish Shihab, tidak serta merta bermakna perang secara fisik. Quraish Shihab menjelaskan bahwa objek jihad itu adalah hawa nafsu, setan, dan berjihad mengangkat senjata melawan musuh. Jihad bisa berbentuk segala upaya pemberantasan atas kebodohan, kemiskinan dan penyakit. ${ }^{65} \mathrm{Jihad}_{\text {, dalam tilikan }}$ Quraish Shihab, bisa berbentuk usaha seorang ilmuwan dalam memanfaatkan ilmunya, seorang karyawan menghasilkan suatu karya dan pekerjaan yang memuaskan bagi tuannya, dan lain sebagainya.

Berdasar elaborasi di atas, tafsir isyari al-Qusyairi penting untuk mengedukasi masyarakat bahwa jihad itu tidak semata bermakna perang dan kekerasan sehingga pendekatan ini bisa menjadi salah satu usaha derdikalisasi penafsiran ayat-ayat jihad. Gerakan islam tradisional seperti sufisme, meminjam analisis Abdurrahman Wakhid, menjadi kritik atas ideologi radikal sekaligus Barat. ${ }^{66}$ Jihad, dalam tilikan al-Qusyairi, adalah upaya pembelaan khususnya ketika diserang dan dideskreditkan, tentunya dengan memperhatikan sejumlah aturan dan kaidah tertentu. Baginya, sasaran jihad adalah kaum kafir yang zalim dan menindas liyan.

\section{Penutup}

Dari paparan di atas dapat disimpulkan pandangan al-Qusyairi terhadap jihad terdapat dalam dua poin yaitu: makna jihad damai (peacefull jihad) dan makna jihad bersenjata (army jihad). Dari sisi makna jihad damai, ia menjelaskan bahwa jihad tidak hanya memiliki makna perang, terkadang ia memakai pendekatan sufi dalam memaknai jihad sehingga makna jihad mencakup fisik dan nonfisik. Jihad dalam artian fisik adalah perang dengan beberapa syarat tertentu. Jihad memiliki tujuan untuk membela nilai-nilai ketuhanan, membela dan membebaskan orang-orang yang tertindas, serta

\footnotetext{
${ }^{64}$ Syarifah Mudrika, "Konsep Jihad Shihab dan Quthb”, Jurnal At-Tibyan: Jurnal Ilmu Alquran dan Tafsir 2 no.1 (Januari-Juni 2017) : 55- 75. https://doi.org/10.32505/tibyan.v2i1.252

${ }^{65}$ Syarifah Mudrika, "Konsep Jihad, 70

${ }^{66}$ Abdurrahman Wakhid, Islamku, Islam Anda, Islam Kita, (Jakarta: The Wahid Institute, 2006), 336
} 
tidak mengabaikan etika peperangan, maka segalanya harus dilakukan selaras dengan etika-etika dan nilai ketuhanan.

Sedangkan signifikansi penafsiran ayat-ayat jihad dalam Latäif al-Isyārät dapat dilihat dari aspek metode dan substansi. Dari aspek metode, pemaknaan al-Qusyairi menjadi penting karena telah menawarkan model pemaknaan yang terbuka, kontekstual, komprehensif, dan tidak dangkal. Pemaknaan demikian lebih mampu untuk apresiatif atas keragaman, sehingga lebih relevan bagi pergaulan antar sesama. Dari sisi substansi, pemaknaan al-Qusyairi terhadap ayat-ayat jihad memperlihatkan konsistensinya dalam memperjuangkan nilai-nilai jihad bukan formalitas an sich. Pemaknaan jihad damai demikian penting guna menegaskan jihad tidak semata bermakna perang dan kekerasan.

\section{DAFTAR PUSTAKA}

Abd. Al- Baqiy, Muhammad Fuad, al-Mu'jām al- Mufahrās li Alfăz Al-Qur'ān alKan̂m, (Beirut: Dār al- Fikr 1992).

Abdillah, Junaidi, "Dekonstruksi Tafsir Ayat-ayat Kekerasan", Jurnal Analisis 11, no.1, (Juni 2011).

Abrar, Arsyad, Epistemologi Tafsir Sufi (Studi terhadap Tafsir al-Sulamī dan alQushayrī), Disertasi UIN Syarif Hidayatullah, Jakarta, 2015.

Abshor, M. Ulil, "Epistemologi Irfani (Sebuah Tinjauan Kajian Tafsir Sufistik)", Jurnal At-Tibyan: Jurnal Ilmu Alqur'an dan Tafsir 3 no. 2, (Desember 2018).

Abu al-Husain Ahmad ibn Faris ibn Zakariya, Mu'jam Maqāyis al-Lugah. Beirut: Dār al Fikr, 1994.

Al-Amin, Habibi, Emosi Sufistik Dalam Tafsir Ishān̄ Studi atas Tafsìr Latā'if alIshārāt Karya al-Qushairī, Disertasi UIN Syarif Hidayatullah, Jakarta, 2015.

Al-Dzahabi, al-Tafsīr wa al-Mufassirûn. Beirut: Dār al-Ma'rifah.t.th.

Al-Isfahani, Al-Raghib, Mu'jām Mufradạt Al-Fāzh Al-Quran. Beirut: Dār al- Fikr 1992.

Al-Jabiri, Abid, Bunyah al-Aql al-Arabi. Beirut: al-Markaz al-Tsaqafi al-Arabi, 1991.

Al-Qardhawi, Yusuf, al-Ṣạ̣wah al-Islāmiyyah Baina al-Juhūd wa al-Tatarruf. Kairo: Bank at-Taqwa, 1989.

, Zāhirah al-Guluw fi Takfir, Mesir: Maktabah Wahbiyyah, 1990.

Al-Qusyairi, Latāàif al-Isyārāt. Beirut: Dar al-Kutub al-Ilmiyyah, 2000.

Algar, Hamid, Principles at Sufisme. Berkeley: Mizan Press, 1990.

As-Shabuni, Rawāì' al-Bayān, Tafsîr Ayāt al-Ahkām min Al-Qur'ān. Beirut: 'Alam Al-Kitab, 1986.

As-Suyuthi, Tabaqāt al-Mufassirîn. Kairo: Maktabah Wahbah.

As-Syathibiy, al-Muwā faqāt. Beirut: Dār al-Ma'rifah. 
Atjeh, Aboebakar, Pengantar Sejarah Sufi \& Tasawwuf. Solo: CV.Ramadhani : 1984. cet.2.

Az- Zarqani, Manāhil al- 'Irfān. Beirut: Dār al-Fikr, t.t.

Az-Zuhailiy, Tafsîr al-Munîr. Beirut: Dar al-Fikr al-Mu'ashir, 1998.

Azra, Azyumardi, Jaringan Ulama timur tengah dan kep. Nusantara abad XVII dan XVIII M.

Baidan, Nasruddin, Metodologi Penafsiran Al-Quran. Yogyakrta: Pustaka Pelajar; 2000. Cet. II.

Baidhawy, Zakiyudin, Konsep Jihad dan Mujahid Damai. Jakarta: Kemenag RI, 2012.

Bakker, Anton dan Achmad Charis Zubair, Metodologi Penelitian Filsafat, Yogyakarta, Kanisius, 1990.

Basyuni, Ibrahim, pengantar Lataif al-Isyārat oleh Al-Qusyairi. Mesir: al-Hayyah alMisriyyah al-Ammah li al-Kitāb, 1971.

Chirzin, Muhammad, "Reaktualisasi Jihad Fi Sabil Allah Dalam Konteks Kekinian Dan Keindonesiaan", jurnal Ulumuna, 10 no. 1 (Januari-Juni 2006).

Faiqoh, Lilik, Unsur-Unsur Isyary Dalam Sebuah Tafsir Nusantara (Telaah Analitis Tafsir Faid al-Rahman Kiai Sholeh Darat) Jurnal At-Tibyan: Jurnal Ilmu Alqur'an dan Tafsir 3 no. 1, (Juni 2018).

Faris, Salman, "Tafsir Esoteris: Studi Pemikiran Nashr Hamid Abu Zayd tentang Penggunaan Ta'wil dalam Tafsir Esoteris”, Dialog, 35, no.1, (Juni 2012).

Ibn al-Qayyim, At-Tibyānn fī Aqsām al-Qur'ān. Beirut: Dār al-Ma'rifah, t.th. Talbis Iblis, Beirut: Dar al-Kitab al-'Arabiy, t.th.

Ibnu Katsir, al-Bidāyah wa al-Nihā yah, vol 2. Kairo: Dar al-Hadiṣ, 1992.

Ibnu Mandzur, Lisān al- 'Arab, Beirut: Dār al - Lisān 'Arab, t.th.

Khalifah, Hajai, Kasyf al-Zunûn, Beirut: Dar al-Kitab al-'Arabiy,t.th.

Machasin, "Sumbangan Hermeneutika Terhadap ilmu Tafsir" Jurnal Studi Agama dan Demokrasi Surabaya bekerjasama dengan The Asia Foundation, 5 no.14, (2003).

Mahfud, Louis, al- Munjid fî al- Lugah. Cet. XVIII. Beirut: Dār al- Maghrib, 1984.

Mudrika, Syarifah, "Konsep Jihad Shihab dan Quthb", Jurnal At-Tibyan: Jurnal Ilmu Alqur'an dan Tafsir 2 no.1 (Januari-Juni 2017).

Muqsith, Abdul, Corak Pemikiran Tasawuf al-Junaid. Jakarta: PPs IAIN Syarif Hidayatullah 1998.

Nasr, Sayyed Hossein dkk. Warisan Sufi "Sufisme Persia Klasik dari Permulaan Hingga Rumi (700-1300)", terj. Gafna Raizha Wahyudi. Yogyakarta: Pustaka Sufi, 2002.

Rahman, Fazlur, Islam. Chicago and London: University of Chicago Press, 1979.

Ridha, Rasyid, Tafsîr al-Manār. Mesir: Maṭba'ah al-Manār, 1349.

Sabiq, Sayyid, Fiqh al-Sunnah. Beirut: Dar al-Fikr, 1983.

Solihin, M., Rosihon Anwar, Ilmu Tasawuf. Bandung: Pustaka Setia, 2008. 
344 De-Radicalization Of Interpretation The Concept Of Jihad In Tafsir Al-Qusyairi - M. Minanur Rohman

Syukur, Amin dan Masyharuddin, Intelektualisme Tasawuf (Studi Intelektualisme tasawuf al-Ghazali). Yogyakarta: Pustaka Pelajar, 2002.

Umar, Nasaruddin, Deradikalisasi Pemahaman al-Qur'an dan Hadis. Jakarta: PT. Elex Media Komputindo, 2014.

Wahid, Abdurrahman, Islamku, Islam Anda, Islam Kita, Jakarta: The Wahid Institute, 2006.

Ziaul Haq, Sansan, "Hermeneutika Sufistik: Telaah Epistemologi Takwil Ibn 'Arabi”". Jurnal At-Tibyan: Jurnal Ilmu Alqur'an dan Tafsir 4 no. 1, (Juni 2019).

Zuhdi, Muhammad Harfin. "Fundamentalism Dan Upauya Deradikalisasi Pemahaman Al-Quran Dan Hadis", Jurnal RELIGIA13, no. 1, (April 2010): 81-102 